\title{
The Right to Inclusive Education of Persons with Disabilities in Italy. Reflections and Perspectives
}

\author{
By Sara Carnovali
}

The paper aims to examine in detail the level of implementation of the right to inclusive education of persons with disabilities stipulated in the Italian legal system, with a particular focus on the Constitution and on the principles stated by the Italian Constitutional Court's case law. The right to education of persons with disabilities is protected through different instruments, constitutional requirements and principles, legislation and case law, and at different territorial levels, representing an emblematic example of integrated or multi-level protection of fundamental rights. However, in reality people with disabilities still face many challenges in accessing education, and this article critically discusses the reform currently planned by the Government designed to address these problems.

Keywords: inclusive education, Italy, persons with disabilities, rights.

\section{The Rules on Inclusive Education}

\section{The Italian Constitution}

The Italian Constitution - in the context of the recognition of fundamental human rights, equal dignity of all citizens and removal of the barriers that prevent the full development and participation of the person - states in Article 34 that "the school is within everyone's reach"1, that "education, given for at least eight years, is compulsory and free" ${ }^{2}$ and that "worthy and capable people, even without any financial mean, have the right to reach the highest levels of education"3.

The guarantee of the right to education also relates to persons with disabilities, as confirmed by Article 38, paragraph 3 of the Constitution, which states that disabled people "have the right to education and vocational training" (Troilo, 2013).

This article has to be read in connection with Article 2, proclaiming that "the Republic recognises and guarantees the inviolable human rights and requires the fulfillment of the mandatory duties of political, economic and social solidarity" 4 . The provision then develops this concept, stating that the person is protected "as an individual and in the social groups within which he expresses his personality" ${ }^{5}$. This article indicates that the inviolable rights' holder is not the isolated individual,

\footnotetext{
${ }^{*}$ Ph.D. Student, University of Milan, Italy.

${ }^{1}$ Article 34, paragraph 1, Italian Constitution.

${ }^{2}$ Ibid., paragraph 2.

${ }^{3}$ Ibid., paragraph 3.

${ }^{4}$ Article 2, Italian Constitution.

5 Ibidem.
} 
but the "person", considered as part of social relations and structures.

From this perspective, Article 3 of the Italian Constitution is particularly important, stating, in addition to the principle of equality of all citizens before the law (formal equality), the duty of the Republic to remove economic and social obstacles able to restrict citizens' freedom and equality (substantive equality): "All citizens have equal social status and are equal before the law, without distinction of sex, race, language, religion, political opinions, and personal or social conditions" 6 . The recognition of equal dignity entails the equal possibility of development of the individual personality, whatever the social and economic position is; the consequence is the illegality of laws that differentiate the treatment of citizens, unless they find their reason in further constitutional rules, able to justify the exemption.

Furthermore, Article 3 states that "It is duty of the Republic to remove economic and social obstacles, which, by restricting the freedom and the equality of citizens, prevent the full development of human being and the effective participation of all workers in the political, economic and social development of the country" ${ }^{7}$. This provision gives the Republic the task of removing the different obstacles that prevent the full enjoyment of individual rights, a task that is strictly connected with the full participation in the national organisation of all workers (to be understood as synonymous with citizens).

\section{The Italian Legislation}

The Italian regulation, widely considered among the most advanced ones both here in Europe and in the world, has abandoned long time ago its original assistance-based approach to embrace the concepts of inclusion and social participation (Karagiannis, Stainback, \& Stainback 1996; Kauffman, 1999; Kavale \& Forness, 2000; Kanter, Damiani, \& Ferri, 2014).

The law no. 118 of 1971 ends the previous regulatory and administrative framework - that established a separation of students with disabilities through the system of special schools and classes - and introduces into our national law the principle of inclusion and educational integration, unless the impairment is serious enough to make impossible or too difficult for disabled student to attend school together with students without disabilities ${ }^{8}$. To ensure inclusive education, measures such as free transport from home to school, the removal of architectural barriers that prevent the access to the school building and the support for students with particularly serious disabilities are $\operatorname{provided}^{9}$ (Madeo, 2010; Troilo, 2013).

\footnotetext{
${ }^{6}$ Article 3, paragraph 1, Italian Constitution.

${ }^{7}$ Ibid., paragraph 2.

8 "The compulsory education has to take place in regular classes of public schools, except when the subjects suffer from serious intellectual deficiencies and physical impairments, so severe that they are able to block or to make really difficult the learning or the inserting in ordinary classes": Article 28, paragraph 2, law no. 118 of 1971.

9 "The maimed and disabled civilians who are not self-sufficient and that attend school or vocational training courses financed by the State have assured: a) free transport from home to the school or to the course and vice versa, at the expense of school patronage or consortia of educational organisations or institutions managing the courses; b) access to the school by
} 
This law represents the first step for a cultural change in the approach to the disability issue: from the so-called "phase of medicalisation", that identifies the individual with the disease from which he suffers, we switch to a conception aimed at developing the specific skills that characterise each individual, therefore also the disabled person ${ }^{10}$ (Valastro, 2006; Paparella, 2010; Troilo, 2013). This choice does not appear obvious, in view of the fact that even today in many countries, some European ones included (e.g., Germany, Belgium and the Netherlands), the education of students with disabilities is taught in special schools or special classes (Powell, 2011; Vislie, 2010; Ainscow \& Haile-Giorgis 1998).

In any case, the definitive abolition of special classes was achieved in 1977 , with the entry into force of the law no. $517^{11}$. This law gives full effect to the principle of inclusive education, a concept that goes beyond the one of mere inclusion in "normal" classes, which, instead of encouraging the active participation of students with disabilities in school life, risks to coincide with the mere presence in the classroom. Law no. 517, instead, aims to achieve an equality that is not only formal, but substantive, through the provision of special education programmes implemented by all the teachers and the introduction of the special education teacher's role ${ }^{12}$ (Cecchini \& McCleary, 1985; Daniels \& Hogg 1991; Abbring \& Meijer, 1994; Vitello, 1994; Berrigan \& Taylor, 1997; Paparella, 2010; D'Alessio, 2011; Arconzo, 2013; Troilo, 2013).

Particular attention has to be devoted to law no. 104 of 1992, which, ensuring the right to education and vocational training of persons with disabilities, confirms the right of disabled students to inclusive education ${ }^{13}$, establishing in Article 12

suitable measures in order to overcome and remove the architectural barriers that prevent its frequency; c) assistance of the most serious invalids during the school hours", Ibid., paragraph 1.

${ }^{10}$ See the International Classification of Functioning, Disability and Health (ICF), the WHO classification for measuring health and disability at both individual and population levels.

11 "The update classes and special classes provided for in Articles 11 and 12 of the law 31 December 1962 n. 1859, shall be abolished": Article 7, last paragraph, law no. 517 of 1977.

12 "As part of these activities the school implements forms of integration in favour of pupils with handicaps with the provision of specialized teachers (...) They must also be ensure the necessary specialist integration, socio-psycho-pedagogical service and special forms of support in accordance with the respective competences of the State and the local authorities, under terms of resource availability and on the basis of the program drawn up by the district school board", "in programming referred to in the preceding paragraph are provided forms of integration and support of pupils with handicaps to be achieved by the use of teachers, tenured or for an unlimited duration, in service in middle school and in possession of particular specialist qualifications, who so request, within the limit of one unit for each class with students with handicaps and up to six hours per week. The classes with pupils with handicaps are made with up to 20 pupils. In these classes the necessary specialist integration, sociopsycho-pedagogical service and special forms of support must be secured within the respective competences of the State and the local authorities, within the limits of available budget and on the basis of the program established by the district school board", Ibid., Articles 2, paragraphs 2 and 3 and 7, paragraphs 2, 3 and 4 .

13 "The inclusion and social integration of the handicapped person are realized by means of measures to make the right to information and the right to education of disabled persons effective, with particular reference to educational and technical equipment, programs, specialized languages, tests evaluation and availability of suitably qualified staff, teaching and non-teaching; (...) measures to facilitate the full integration into the working world, individually or collectively, and the 
that the inclusion in nursery schools and the attendance in ordinary classes of any level and university institutions ${ }^{14}$ must be guaranteed. In fact, inclusive education represents a fundamental prerequisite for the full development of the person and in particular of his potential "in learning, communication, relationships and socialisation" ${ }^{15}$; so, learning difficulties or other special needs cannot justify a restriction of his right to education ${ }^{16}$.

Law 104 is certainly one of the most important provisions in the field, the milestone of the entire legislation that aims to ensure the right to education of persons with disabilities (Abbring \& Meijer, 1994; OECD, 1999). In this regard, law no. 104 and its various implementing regulatory acts ${ }^{17}$ provide that, within 30 days since the submission of the registration request by the family, the competent medical commission must issue the so-called "Certification of the student with special needs", to be filed with the educational establishment where the student will be enrolled in good time for a timely preparation of the "Functioning diagnosis". The diagnosis, in line with the ICF classification, will already include the "Dynamic-functional profile", corresponding to the functioning profile of the person and which will form the basis for the subsequent preparation of the "Individualised Education Plan" (P.E.I.), a document that outlines the integrated interventions - in the areas of education, socialisation and learning - drawn in favour of the individual student with disabilities, in view of his specific characteristics and abilities, in order to be able to guarantee him the widest possible participation and inclusion during the implementation of his fundamental right to education by public institutions. To this end, an integral part of the P.E.I. is the so-called "Project of life", which concerns the entire development of the student with disabilities, both outside and beyond the school walls (Abbring \& Meijer, 1994; Eurypedia-Italy, 2012; Ianes, Demo, \& Zambotti, 2014).

On the basis of the framework described above, it is clear that the Italian legislation is intended to place the student, in full respect of his individuality and unique personality, at the centre of a process of careful consideration of his needs, growth and development.

This approach places the Italian national legislation - in the abstract - in line with the requirements of the UN Convention on the Rights of Persons with Disabilities, ratified by Italy in 2009 and, in December 2010, also by the European Union. During the work on the development of the Convention, the official Italian delegation has made a strong contribution to Article 24, on the right to education.

protection of employment through diversified incentives": Article 8, letters d) and f), law no. 104 of 1992.

14 "The handicapped child from 0 to 3 years old has a guaranteed right to integration in kindergartens. It is guaranteed the right to education of the handicapped person in the sections of kindergarten, in mainstream classes of educational institutions of all levels and in the universities": Ibid., Article 12, paragraphs 1 and 2.

${ }^{15}$ Ibid., paragraph 3.

16 "The exercise of the right to education cannot be prevented by learning difficulties or other difficulties deriving from disabilities connected with the handicap": Ibid., paragraph 4.

${ }^{17}$ See Presidential Decree 24 February 1994; Articles 312-325 of Legislative Decree no. 297 of 1994; Prime Ministerial Decree no. 185 of 2006; Unified Conference State and Regions' Agreement of 20 March 2008; Guidelines on educational integration of students with disabilities of 4 August 2009. 
In many countries of the world there are special schools devoted to students with disabilities. Italy, among others, by owning a legislation dating back to the seventies of the last century, has instead argued for and succeeded in enshrining the right to full education of students with disabilities in mainstream schools. (Foggetti, 2006; Seatzu, 2008; Marra, 2010; Griffo, 2012). Accordingly, the signatory States to the Convention shall ensure to persons with disabilities an inclusive education system at all levels and a lifelong learning, on an equal basis with others, including the adoption of personalised forms of communication and supporting measures, with the goal of full inclusion and within the general education system. Moreover, education must be able to promote social participation, the sense of dignity, self-esteem and the full development of disabled persons' abilities ${ }^{18}$ (Kanter, Damiani, \& Ferri, 2014; WEAC.org, 2015).

This view is in line with the Italian Constitutional Court, which has always claimed since the judgment no. 215 of 1987 that: "the participation in the educational process with teachers and able-bodied companions is (...) an important factor of socialisation and can significantly contribute to stimulating

\footnotetext{
18 "1. States Parties recognize the right of persons with disabilities to education. With a view to realizing this right without discrimination and on the basis of equal opportunity, States Parties shall ensure an inclusive education system at all levels and life long learning directed to: a) The full development of human potential and sense of dignity and self-worth, and the strengthening of respect for human rights, fundamental freedoms and human diversity; b) The development by persons with disabilities of their personality, talents and creativity, as well as their mental and physical abilities, to their fullest potential; c) Enabling persons with disabilities to participate effectively in a free society. 2. In realizing this right, States Parties shall ensure that: 1) Persons with disabilities are not excluded from the general education system on the basis of disability, and that children with disabilities are not excluded from free and compulsory primary education, or from secondary education, on the basis of disability; 2) Persons with disabilities can access an inclusive, quality and free primary education and secondary education on an equal basis with others in the communities in which they live; 3) Reasonable accommodation of the individual's requirements is provided; Persons with disabilities receive the support required, within the general education system, to facilitate their effective education; 4) Effective individualized support measures are provided in environments that maximize academic and social development, consistent with the goal of full inclusion. 3. States Parties shall enable persons with disabilities to learn life and social development skills to facilitate their full and equal participation in education and as members of the community. To this end, States Parties shall take appropriate measures, including: a) Facilitating the learning of Braille, alternative script, augmentative and alternative modes, means and formats of communication and orientation and mobility skills, and facilitating peer support and mentoring; b) Facilitating the learning of sign language and the promotion of the linguistic identity of the deaf community; c) Ensuring that the education of persons, and in particular children, who are blind, deaf or deafblind, is delivered in the most appropriate languages and modes and means of communication for the individual, and in environments which maximize academic and social development. 4. In order to help ensure the realization of this right, States Parties shall take appropriate measures to employ teachers, including teachers with disabilities, who are qualified in sign language and/or Braille, and to train professionals and staff who work at all levels of education. Such training shall incorporate disability awareness and the use of appropriate augmentative and alternative modes, means and formats of communication, educational techniques and materials to support persons with disabilities. 5. States Parties shall ensure that persons with disabilities are able to access general tertiary education, vocational training, adult education and lifelong learning without discrimination and on an equal basis with others. To this end, States Parties shall ensure that reasonable accommodation is provided to persons with disabilities", Article 24, UN Convention on the Rights of Persons with Disabilities.
} 
the potential of the disadvantaged, i.e. the unfolding of the psychological stresses and improvements to their processes of learning, communication and relationship (...). The school attendance is thus a key factor of recovery of the person (...) and overcoming his exclusion, in a complex weave in which each of those elements interacts on the other, and, if there is a positive evolution, it can operate in a synergistic function for the purpose of overall development of the personality"19.

\section{The Current and Concrete Situation}

\section{Reflections}

Based on the regulatory framework described above, it is easy to state that Italy is a context strongly marked by the most extensive and effective guarantee of disabled people's right to education, with an approach wholly based on inclusion, focused on both human rights enucleated from the UN Convention, and fundamental principles of participation and full respect of the person enshrined in the Italian Constitution.

However, as unfortunately happens sometimes, the legal framework is different from the reality which students with disabilities face every day. The data emerging from the most recent studies conducted by the various organisations that deal with the protection of the rights of persons with disabilities reveal a problematic picture, which consists of inadequate teaching aids, delays and inefficiencies in the area inclusive education services (Devecchi, Dettori, Doveston, Segdwick, \& Jament, 2012; Di Nuovo, 2012).

According to Article 139 of the legislative decree no. 112 of 1998, the municipalities have functions as regard to transport and educational assistance with respect to nursery, primary and secondary school; the provinces have the same functions with respect to secondary school $^{20}$ and those relating to assisting communication for students with sensory disabilities who attend all educational levels ${ }^{21}$. However, the law no. 56 of 2014 intervened recently on this division of powers, without explaining - in redefining features and functions of the various local authorities - how to redraw the attribution of responsibilities in the management of organisational education support services for students with disabilities.

The result of this "oversight" has been the failure to start of some of these services, or the delay in their provision or the inability to respond to recipients' actual needs. The situation varies greatly from place to place, with the further consequence that, in view of equal situations, institutions respond differently, or even do not respond at all, with serious repercussions in the field of equality, reasonableness and equal opportunities, contrary to article 3 of the Italian Constitution, as well as the legislation on the topic.

It is clear that the situation is highly fragmented in the first place, in light

\footnotetext{
${ }^{19}$ Italian Constitutional Court, sentence no. 215 of 1987, in law, no. 5.

${ }^{20}$ See Article 37, paragraph 1, letter c), legislative decree no. 112 of 1998.

${ }^{21}$ See Article 5, law no. 67 of 1993.
} 
of the fact that the treatment of people with disabilities is different and depends on the place of residence; moreover, such a treatment is inadequate to protect effectively the right to education of children with disabilities, especially of those who suffer from the most serious diseases and therefore are more at risk of dropping out of school early.

If, despite such a situation as the one highlighted, some students with disabilities are still able to go to school it is thanks to the fact that families bear the costs, both of the transport, and - sometimes - even of educational assistance, as well as that many schools have used resources destined for other purposes ${ }^{22}$. This is a clear case of economical discrimination, which openly contrasts with the principle of substantive equality. Indeed, it is duty of the Republic, implementing the dictates of Article 3, paragraph 2 of the Italian Constitution, to remove the obstacles - both economic and social - that limit the freedom and equality of citizens, and so preventing the full development of their personality and the actual participation in the life of the community where they live. The materialisation of this principle in the context of the right to education consists in providing students with disabilities equal opportunities in the enjoyment of school services, avoiding not only direct ${ }^{23}$, but also indirect discrimination $^{24}$.

Transport services, educational assistance and assistance to communication are an essential support in order to ensure to persons with disabilities the right to education. As repeatedly pointed out also by the Italian Constitutional Court, the right to inclusive education is a fundamental right, and therefore there is no justification for the failure to protect it due to lack of organisation and coordination by the competent local authorities ${ }^{25}$. Delays or failures in triggering these services represent, therefore, unjustified discrimination.

Moreover, operations of removing the obstacles that, due to the presence of a disability, can prevent students from fully enjoying their fundamental right to education, should be characterised by adequacy, customisation, verifiability and modifiability over time, if necessary. As well as assistance to communication, educational assistance and transportation, measures supporting inclusion in the school also consist of special education teachers, primary care and individualised interventions and programmes which take into account the specific characteristics and needs of the student ${ }^{26}$.

\footnotetext{
${ }^{22}$ See Ledha, Lega per i diritti delle persone con disabilità/league for the rights of people with disabilities website: www.ledha.it.

23 "Direct discrimination occurs when, for reasons related to disability, a person is treated less favourably than another is, has been or would be treated a non-disabled person in a similar situation": Article 2, paragraph 2, law no. 67 of 2006. See, moreover, Article 2, paragraph 2, letter a) of the directive 2000/78/EC.

24 "An indirect discrimination occurs when a provision, a criterion, a practice, an act, a pact or an apparently neutral behaviour put a disabled person at a disadvantage compared with other persons": Ibid., paragraph 3. See, moreover, Article 2, paragraph 2, letter b) of the directive 2000/78/EC.

${ }^{25}$ See sentence no. 80 of 2010 of the Italian Constitutional Court, which will be analyzed later.

${ }^{26}$ This because, as the Italian Constitutional Court has always pointed out, "people with disabilities are not a homogeneous group. There are, in fact, different forms of disabilities: some have a mild character and other a serious one. For each of them it is necessary, therefore, to identify the barriers
} 
These measures, in order to be effective, should be carried out according to specific timelines and procedures based on cooperation and coordination between various bodies and institutions, a situation that does not always occur according to relevant research (Carrington \& Robinson, 2006; Ainscow \& Sandill, 2010; Florian \& Linklater, 2010; NESSE, 2012).

\section{Perspectives}

The Italian Government is now committed to developing, as delegated by the Parliament, a reform of the school system, which has as its objectives, among others, the "promotion of school inclusion of students with disabilities" and "recognition of the different ways of communication" ${ }^{27}$. In this section, I provide an analysis of some of the most important issues in relation to which the Government is called upon to regulate the matter of education.

First, the project aims to redesign the special education teacher's training, since its early stages - through the separation of careers and the provision of differentiated public competitions -, in order to effectively ensure the right to education of persons with disabilities ${ }^{28}$. This point has given rise to a heated debate. Some associations and experts are critical, stating that the separation of teachers' university education and careers would encourage the mechanism of delegation, threatening a real integration. According to another approach, instead, the specialisation represents the best instrument to strengthen all teachers' skills, as well as the relationship between the special education teachers and students with disabilities $^{29}$ (Giacobini, 2015; Ferraro, 2015; Redazione, 2015). On the other hand, those who are dealing with the drafting of the executive decree claim that this choice is aimed to enhance the role of the special education teacher, in order to make the right to inclusive education as effective as possible, through a better preparation of professionals.

Second, the project includes the review of the criteria for the inclusion in educational support roles, by offering the student the same teacher for the entire level of education. The objective is to ensure students with disabilities a continuity of the relationship with the teacher. That provision is closely linked to those examined above, aimed at teachers' professional specialisation.

Third, the project includes a review of the procedures and criteria for the certification of disability, which should be aimed at identifying the residual abilities in order to develop them through paths identified in consultation with all the specialists. This standard is hopefully to be understood in the sense of a shrinking medicalisation of disability and an increase of attention paid to the development of the person's residual abilities, with a view not merely welfarebased, but inclusive, corresponding to the bio-psycho-social model, implemented

removal mechanisms that take into account the type of disability that affect in practice a person": sentence no. 80 of 2010 , in law, no. 3 .

${ }^{27}$ See Article 1, paragraph 181, letter c), law no. 107 of 2015.

${ }^{28}$ Ibid., paragraph 110.

${ }^{29} \mathrm{Cf}$. on this topic the different positions of the main Italian associations for the rights of people with disabilities, with a specific reference - among others - to Ledha, Fish, Anffas. In particular, see the links http://bit.ly/2xXJvyu; http://bit.ly/2yBcYO9. 
in 2006 by the UN Convention on the Rights of Persons with Disabilities. This model defines "disability" as the consequence or the result of a complex interaction between the health condition of the individual and contextual factors: the person is not considered only in his individuality, but also in relation to his surroundings, physical and social ${ }^{30}$.

Fourth, the provision of the initial and in-service training obligation is particularly important, mainly for two different reasons. On one hand, there is a particular focus on the pedagogical-didactic and organisational aspects of inclusive education for school leaders and teachers. On the other hand, inclusion consists also of basic assistance and organisational and educational-relational training for the administrative, technical and auxiliary staff, with regard to specific competences. This requirement expresses the view that the guarantee of the right to education of students with disabilities cannot be delegated only to special education teachers, but must first involve the school principal and then the entire staff - teaching and non-teaching -, in order to achieve the highest possible interaction between students with disabilities and the rest of the class. In this regard what is already laid down in the Guidelines of the Ministry of Education of 4 August 2009 acquires special importance; namely, it is stated that "it is the whole school community that must be involved in the process in question and not just a specific professional figure to whom the task of integration is exclusively delegated $" 31$.

Fifth, the project aims to implement the right to home education for children with disabilities that are still subject to compulsory education but temporarily prevented from attending school for health reasons ${ }^{32}$. This right is now far from guaranteed, at least without delay and with effectiveness. It is to be hoped that the status quo will change.

Finally, some provisions of the draft discussed above refer to the "limits of available resources". In this regard, the legislator will need to keep in mind what has been stipulated by the Italian Constitutional Court in judgment no. 80 of 2010, where it was ruled that, although the legislator has discretion in the identification of the measures needed to protect the rights of persons with disabilities, "discretion is not absolute and is limited by the respect of an untouchable core of guarantees for those concerned" ${ }^{33}$, coinciding with the services that are essential to implement the right to inclusive education, thus preventing it from remaining an empty formula on paper.

\footnotetext{
30 "Disability is an evolving concept (...) that (...) results from the interaction between persons with impairments and attitudinal and environmental barriers that hinders their full and effective participation in society on an equal basis with others": Preamble, letter e), UN Convention on the Rights of People with Disabilities.

${ }^{31}$ Guidelines on educational integration of students with disabilities of 4 August 2009, no. 2.5, The teacher assigned to support activities, 18.

${ }^{32}$ See Article 12, paragraph 9, law no. 104 of 1992.

${ }^{33}$ Italian Constitutional Court, sentence no. 80 of 2010, in law, no. 4.
} 


\section{Conclusions}

As described previously, the Italian legal framework is in general strongly marked by the most extensive and effective guarantee of the right to education of persons with disabilities, with an approach wholly based on inclusion, focused on both human rights enucleated from the United Nations Convention, and fundamental principles of participation and full respect of the person enshrined in the Italian Constitution.

However, the reality is characterised - along with examples of good functioning of the school inclusion model - by delays and inefficiencies in the delivery of services by public authorities. It is to be hoped that the reform under consideration will solve these issues, always bearing in mind that "disability" is the consequence or the result of a complex interaction between the health condition of the individual and contextual factors, and that the disabled person must not be considered only in his individuality, but mostly in relation to his surroundings, physical, behavioural and social ${ }^{34}$.

\section{References}

Abbring, I., \& Meijer, C.J.W. (1994). Italy. In C.J.W. Meijer, S.J. Pijl, \& S. Hegarty, (Eds.), New Perspectives in Special Education, (pp. 9-24). London: Routledge.

Ainscow, M., \& Haile-Giorgis M. (1998). The Education of Children with Special Needs: Barriers and Opportunities in Central and Eastern Europe. UNICEF, Firenze.

Ainscow, M., \& Sandill, A. (2010). Developing Inclusive Education Systems: The Role of Organisational Cultures and Leadership. International Journal of Inclusive Education, 14, 401-416.

Arconzo, G. (2013). La normativa a tutela delle persone con disabilità nella giurisprudenza della Corte costituzionale [The legislation for the protection of people with disabilities in the case law of the Constitutional Court]. In M. D'Amico, \& G. Arconzo, (Eds), Università e persone con disabilità. Percorsi di ricerca applicati all'inclusione a vent'anni dalla legge n. 104 del 1992, (pp. 17-32). Milano: Franco Angeli.

Berrigan, C., \& Taylor, D. (1997). Everyone belongs: School inclusion and social relationships in Italy. TASH Newsletter, 21-22.

Carrington, S., \& Robinson, R. (2006). Inclusive School Community: Why Is It So Complex? International Journal of Inclusive Education, 10, 323-334.

Cecchini, M., \& McCleary, I.D. (1985). Preschool handicapped in Italy: A research-based developmental model. Journal of the Division for Early Childhood, 9, 254-265.

D'Alessio, S. (2011). Inclusive Education in Italy: A critical analysis of the

\footnotetext{
34 "(...) Disability results from the interaction between persons with impairments and attitudinal and environmental barriers that hinders their full and effective participation in society on an equal basis with others", Preamble, letter e), UN Convention on the Rights of People with Disabilities.
} 
policy of "integrazione scolastica". Rotterdam, Netherlands: Sense Publishers.

Daniels, H., \& Hogg, B. (1991). An intercultural comparison of the quality of life of children and youth with handicaps in Denmark, Italy, the United Kindom, and Germany. Educational and Child Psychology, 8, 74-83.

Devecchi, C., Dettori, F., Doveston, M., Segdwick, P., \& Jament, J. (2012). Inclusive Classrooms in Italy and England: The Role of Support Teachers and Teaching Assistants. European Journal of Special Needs Education, 27, 171-184.

Di Nuovo, S. (2012). Rethinking Inclusion and Its Conditions: A Reply to Giangreco, Doyle \& Suter (2012). Life Span and Disability, 15(2), 75-83.

Eurypedia - Italy. (2012). Special Education Needs Provision within Mainstream Education. Retrieved from http://bit.ly/2yCA0nO.

Ferraro, A. (2015). Una serie di proposte per la riforma del sostegno [A series of proposals for reforming the support teaching]. Retrieved from http://bit. $1 \mathrm{y} / 2 \mathrm{gv0qx} 3$.

Florian, L., \& Linklater, H. (2010). Preparing Teachers for Inclusive Education: Using Inclusive Pedagogy to Enhance Teaching and Learning for All. Cambridge Journal of Education, 40, 369-386.

Foggetti, N. (2009). Diritti umani e tutela delle persone con disabilità: la Convenzione delle Nazioni Unite [Human rights and the protection of people with disabilities: the United Nations Convention]. Rivista della Cooperazione Giuridica Internazionale, 33, 98-118.

Giacobini, C. (2015). "Buona scuola" e studenti con disabilità ["Buona scuola" and students with disabilities]. Retrieved from http://bit.ly/2gCnldC.

Griffo, G. (2012). Le ragioni della Convenzione sui diritti delle persone con disabilità delle Nazioni Unite [The reasons for the United Nations Convention on the Rights of Persons with Disabilities]. In O. Osio, \& P. Braibanti (eds), Il diritto ai diritti. Riflessioni e approfondimenti a partire dalla Convenzione ONU sui diritti delle persone con disabilità, (pp. 39-45). Milano: Franco Angeli.

Ianes, D., Demo, H., \& Zambotti, F. (2014). Integration and Inclusion in Italy. Towards a Special Pedagogy for Inclusion. ALTER European Journal of Disability Research, 8, 92-104.

Kanter, A. S., Damiani, M.L., \& Ferri, B.A. (2014). The Right to Inclusive Education under International Law: Following Italy's Lead. Journal of international Special Needs Education, 17, 21-32.

Karagiannis, A. Stainback, W., \& Stainback, S. (1996). Rationale for inclusive schooling. In S. Stainback, \& W. Stainback (Eds), Inclusion: a guide for educators, (pp. 3-16). Baltimore: Brookes.

Kauffman, J.M. (1999). Commentary: Today's special education and its messages for tomorrow. The Journal of Special Education, 32, 244-254.

Kavale, K.A., \& Forness, S.R. (2000). History, rhetoric and reality: Analysis of the inclusion debate. Remedial and Special Education, 21, 279-296.

Madeo, F. (2010). Insegnante di sostegno: possibile la presenza per tutte le ore di frequenza scolastica dello studente disabile grave. Giurisprudenza costituzionale, II, 1831-1839. 
Marra, A. (2010). La protezione dei minori con disabilità in Italia dopo la Convenzione delle Nazioni Unite del 2006 [Protection of children with disabilities in Italy after the United Nations Convention in 2006]. Minorigiustizia, III, 25-39.

NESSE (Network of Experts in Social Sciences of Education and Training). (2012). Education and Disability/Special Needs. Policies and Practices in Education, Training and Employment for Students with Disabilities and Special Education Needs in the EU. Brussels: European Commission, DG Education and Culture.

OECD, (1999). Inclusive Education at Work: Students with Disabilities in Mainstream Schools. Paris: OECD.

Paparella, E. (2010). Il diritto all'integrazione e all'istruzione scolastica dei soggetti diversamente abili: una fondamentale declinazione del diritto allo studio nella prassi amministrativa e nelle recenti pratiche governative [The right to integration and school education of disabled people: a fundamental declination of the right to study in administrative practice and in recent government practices]. In Studi in onore di Vincenzo Atripaldi, (pp. 961-987). Napoli: Jovene editore.

Powell, J.J.W. (2011). Barriers to Inclusion. Special Education in the United States and Germany. New York: Routledge.

Redazione. (2015). Il problema dell'inclusione non è il numero degli insegnanti di sostegno [The issue of inclusion is not the number of support teachers]. Retrieved from http://bit.ly/2xXJvyu.

Seatzu, F. (2008). La Convenzione delle Nazioni Unite sui diritti delle persone disabili: i principi fondamentali [The United Nations Convention on the Rights of Persons with Disabilities: the Fundamental Principles]. Diritti umani e diritto internazionale, III, 535-559.

Troilo, S. 2013. I "nuovi" diritti sociali: la parabola dell'integrazione scolastica dei disabili [The "new" social rights: the parable of the integration of disabled people]. In I diritti sociali dal riconoscimento alla garanzia: il ruolo della giurisprudenza: atti del Convegno di Trapani 8-9 giugno 2012, Quaderni del Gruppo di Pisa, (pp. 535-544). Napoli: Editoriale Scientifica.

Valastro, A. (2006). Le vicende giuridiche dell'handicap e la "società dell' informazione": vecchie conquiste e nuove insidie per la Corte costituzionale [The legal affairs of the handicap and the "information society": old conquests and new pitfalls for the Constitutional Court]. In A. Pace, (ed.), Corte costituzionale e processo costituzionale nell'esperienza della rivista "Giurisprudenza costituzionale" per il cinquantesimo anniversario, (pp. 9881020). Milano: Giuffrè.

Vislie, L. (2010). From integration to inclusion: focusing global trends and changes in the western European societies. In European Journal of Special Needs Education, 1, XVIII, 17-35.

Vitello, S.J. (1994). Special education integration: The Arezzo approach. International Journal of Disability Development and Education, 41, 61-70.

WEAC.org. (2015). 